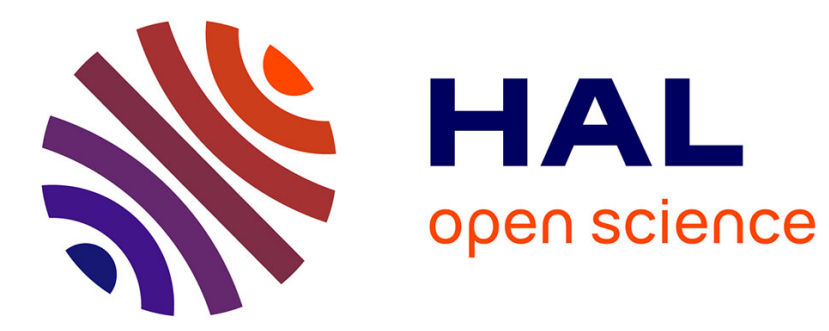

\title{
The influence of cutting force on surface machining quality
}

Xinmin Fan, M Loftus

\section{To cite this version:}

Xinmin Fan, M Loftus. The influence of cutting force on surface machining quality. International Journal of Production Research, 2007, 45 (04), pp.899-911. 10.1080/00207540600632208 . hal-00512894

\section{HAL Id: hal-00512894 \\ https://hal.science/hal-00512894}

Submitted on 1 Sep 2010

HAL is a multi-disciplinary open access archive for the deposit and dissemination of scientific research documents, whether they are published or not. The documents may come from teaching and research institutions in France or abroad, or from public or private research centers.
L'archive ouverte pluridisciplinaire HAL, est destinée au dépôt et à la diffusion de documents scientifiques de niveau recherche, publiés ou non, émanant des établissements d'enseignement et de recherche français ou étrangers, des laboratoires publics ou privés. 


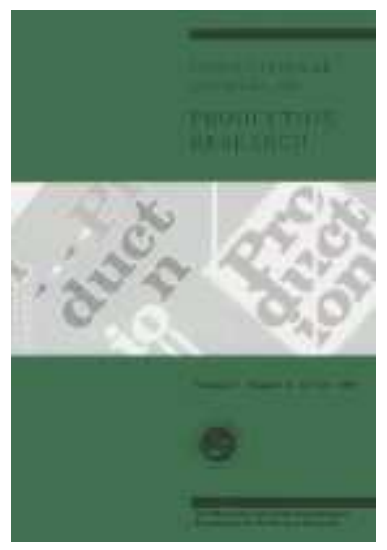

\section{The influence of cutting force on surface machining quality}

\begin{tabular}{|r|l|}
\hline Journal: & International Journal of Production Research \\
\hline Manuscript ID: & TPRS-2005-IJPR-0352.R1 \\
\hline Manuscript Type: & Original Manuscript \\
\hline Date Submitted by the \\
Author: & 10 -Feb-2006 \\
\hline Complete List of Authors: & $\begin{array}{l}\text { Fan, Xinmin; The University of Warwick, Warwick manufacturing } \\
\text { group } \\
\text { Loftus, M; University of Birmingham, School of Mfg and Mech } \\
\text { Engineering }\end{array}$ \\
\hline Keywords: & $\begin{array}{l}\text { FLEXIBLE MANUFACTURING, CNC MACHINING, ADVANCED } \\
\text { MANUFACTURING PROCESSES, CAM, ADVANCED MANUFACTURING } \\
\text { TECHNOLOGY }\end{array}$ \\
\hline Keywords (user): & Ball-end mill, cutting force model, machining quality \\
\hline
\end{tabular}

\section{s ScholarONE" \\ Manuscript Central}




\title{
The influence of cutting force on surface machining quality \\ $\mathrm{X}$. FAN* and M. LOFTUS $\dagger$
}

Keywords:

Ball-end mill, cutting force model, machining quality

\begin{abstract}
Appropriately controlled cutting forces can contribute not only to the safety and efficiency of machining but also to the quality of machined surfaces. It is even more important when hardened material is cut. The correlation between the cutting force and the surface quality in ball-end milling operations has been investigated by machining P20 steel (HRC 30) work-pieces using solid carbide ball-end cutters. Plane surfaces with different depth of cut were machined using two different cutting strategies. The first strategy cut the test-piece using a cutting force model, whereas the other machined with a feed rate optimisation product, which uses the removal rate as an analogue of cutting force to control the feed rate. The test results show that constant surface quality is possible when the cutting forces are controlled through feed rate adjustment. Conversely, a desired surface quality can also be maintained by controlling the cutting force in a predetermined manner.
\end{abstract}




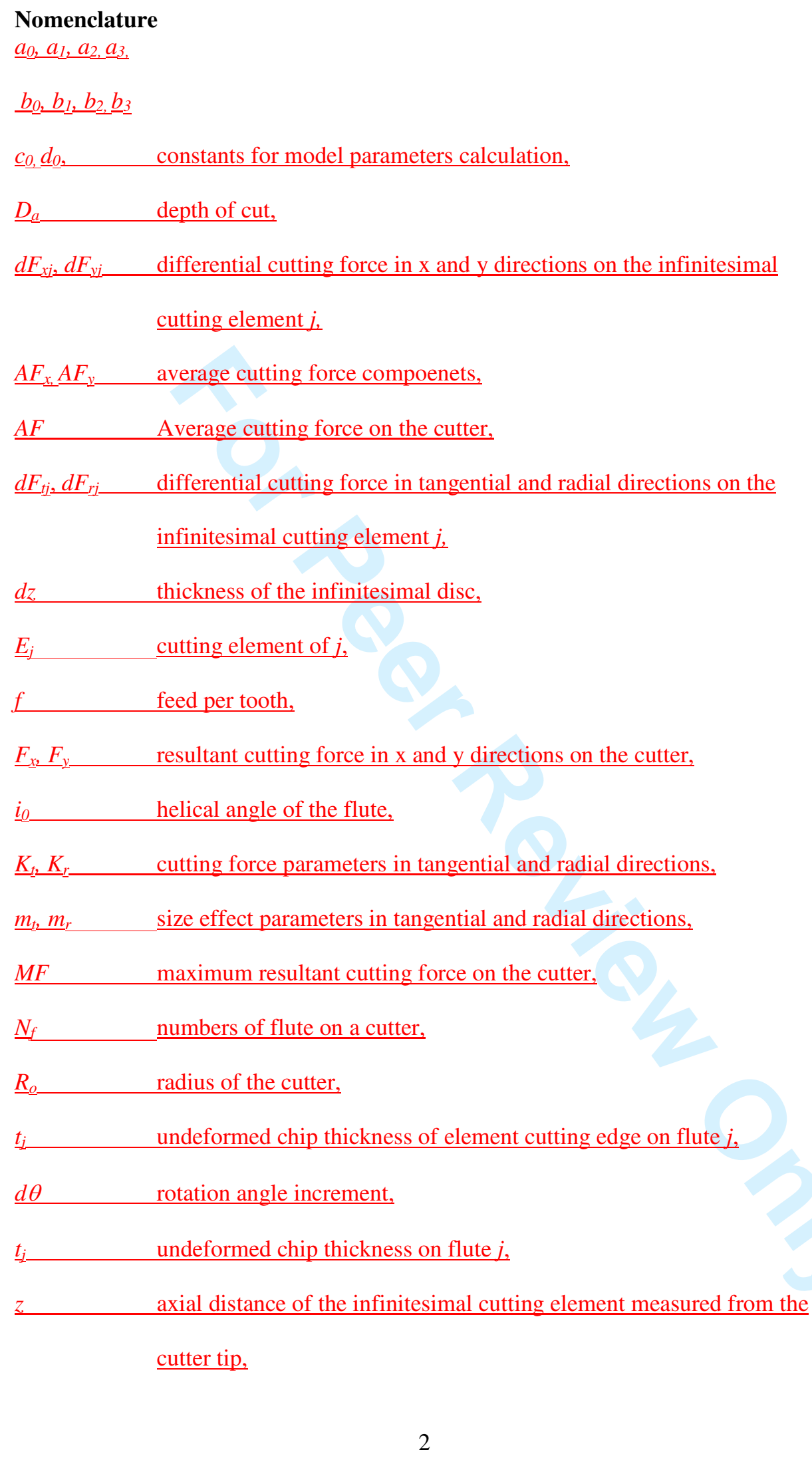


1

2

3

4

5

6

7

8

9

10

11

12

13

14

15

16

17

18

19

20

21

22

23

24

25

26

27

28

29

30

31

32

33

34

35

36

37

38

39

40

41

42

43

44

45

46

47

48

49

50

51

52

53

54

55

56

57

58

59

60

$\mid$\begin{tabular}{ll}
$\underline{\theta}$ & cutter rotation angle measured from the referenced flute at cutter tip, \\
\hline$\Phi$ & lag of the cutting element on referenced flute, distanced $z$ from cutter \\
$\underline{\Psi_{j}}$ & $\underline{\text { tip, }}$ \\
& $\begin{array}{l}\text { angular position of the cutting element on flute } j, \text { distanced z from the } \\
\underline{\delta}_{j}\end{array}$
\end{tabular} 
1. 1 Introduction

Research initiatives to investigate the correlation of the cutting parameters within the milling process have been conducted over the years. Merchant (1945) pioneered this work and reported the fundamental relationship between the cutting parameters and the cutting force in orthogonal cutting application. Martelloti (1941, 1945) demonstrated that feed per tooth is one of the most important cutting parameters to determine the removed chip volume and other milling parameters. Sabberwal (1960) suggested the empirical relationship between the cutting force and undeformed chip volume in end milling operations. Lin and Yang (1995) and Sarhan et al (2001) reported that the variable cutting force can cause quick tool wear, and may be dangerous in high speed machining applications. Devor (1998), Gadalla and Elmaraghy (1998) and Bouzakis et al (2003) commented on the requirements for a constant cutting force during the machining operation for a satisfactory surface quality. Research on feed rate optimisation to obtain appropriate cutting conditions have also been reported. Bergs and Altintas (1996), Chu et al (1997) proposed an approach of feed rate optimisation in ball-end milling applications.

Cutting force is considered to be one of the most important physical output variables in a machining process ( Bayoumi A E, at el 1994 ), because it affects the machining quality (Yun W S, at el 2002), and compromises the efficiency and safety of the whole machining process. It is even more important in die and mould machining where the material is hard and the component shapes are complicated. Cutting force controlled machining has attracted interest from industry, with commercial software available to control the cutting forces when cutting conditions vary. For example, PSOptiFeed (developed by Delcam International plc) is a feed rate optimisation 
product which attempts to maintain a constant cutting load by adjusting the feed rate as cutting conditions vary.

The effect of cutting force on machining quality in ball-end mill machining is presented in this paper, which is organised into four sections: cutting force model parameter calibration, plane surface machining with a cutting force model, plane surface machining with feed rate optimisation software and a concluding section. Plane surface machining trials were conducted to assess the effect of cutting force on the machining quality in P20 tool steel. The test-pieces have three stepped surfaces with different depths of cut on each surface. The machining trials were conducted using two different cutting force control strategies. The first maintained the cutting force at a constant value in the variable depth of cut surfaces using a cutting force model. The second employed commercial feed rate optimisation software in the variable depth of cut conditions. The principle of the feed rate optimisation software is to maintain a constant cutting load, but instead of cutting force, it uses the removed chip volume as an analogue of the cutting load. An existing infinitesimal flute ballend mill cutting force model (Feng and Meng, 1994) was used to calculate the cutting force. The model parameters of this cutting force model for machining of P20 tool steel using solid carbide ball-end mill were determined by a set of calibration tests. In model parameter calibration, a modified method is used to evaluate the model parameters using the slot milling test data. In the plane surface machining with a cutting force model section, the feed rates derived from the cutting force model, in a variable depth of cut situation, are considered. The actual cutting forces generated during the machining trials were recorded and compared with the simulated values. The results of the machining quality and the cutting force during the surfaces 
machining are analysed. In the plane surface machining by feed rate optimisation software section, the machining quality and the recorded cutting force during the machining trial for a similar test-piece is presented along with a comparison of the machining quality from the cutting force model.

The material of the test-pieces used in the machining trials was P20 steel with a hardness value of $\mathrm{HRC} 30$. The cutters were $8 \mathrm{~mm}$ diameter, 2-flute with $30^{\circ}$ helical angles, solid carbide ball-end mills.

\section{Calibration of a cutting force model for milling P20 steel}

Many cutting force models have been developed over time, but the practical application of cutting force models is limited due to their empirical characteristics and the model parameters being restricted to a few popular work-piece materials. As addressed by Luttervelt Van (1998), the kernel of the empirical cutting models is the calibration of the model parameters for the specific work-piece material and cutter combination. The infinitesimal flute cutting force model of Feng and Meng (1994) was developed for ball-end mill cutting force calculation. It has a simpler system to calibrate the model parameters than other ball-end mill cutter models (Yang and Park 1991, Lee and Altintas 1996). The curved cutting edges of the ball-end mill cutter are considered as a series of infinitesimal cutting elements, as shown in Figure 1.

Suppose the reference of the cutter rotation is at the tip point of flute 1 , and the cutter has a number of helical flutes, $N_{f}$, Figure 1 (c). Owing to the helix angle, $i_{0}$, of the $\underline{\text { flute, Figure } 1 \text { (a), the lag of a cutting element, } z \text {, on flute 1, Figure } 1 \text { (b) and (c), can }}$ be given as: 


$$
\Phi=\theta-\frac{z}{R_{0}} \tan i_{0}
$$

Therefore, the angular position of a cutting element of flute $j$ on a disc $z$, Figure 1 (b), from the cutter tip can be calculated by:

$$
\Psi_{j}=\theta-\frac{z}{R_{0}} \tan i_{0}+(j-1) \frac{2 \pi}{N_{f}}
$$

Deleted:

Formatted: Font color: Auto

where $\theta$ is the rotation angle of the reference flute 1 at the tip of the cutter. The undeformed chip thickness $t_{j}$ of a cutting element, $E_{j}$, can be given by:

$$
t_{j}=\left|f \sin \Psi_{j}\right|
$$

Formatted: Indent: First line: $36 \mathrm{pt}$ Formatted: Lowered by $8 \mathrm{pt}$

$\underline{\text { Considering the size effect, the differential tangential and radial cutting forces }} d F_{t j}$ and $d F_{r j}$ on an element can be calculated by:

$$
\begin{aligned}
& d F_{t j}=K_{t} t_{j}^{m_{t}} d z \\
& d F_{r j}=K_{r} t_{j}^{m_{r}} d z
\end{aligned}
$$

where, $m_{t}$, and $m_{r}$ are the size effect parameters. $K_{t}$ and $K_{r}$ are the tangential and radial specific cutting pressures. $d z$ is the thickness of the disc. The differential tangential and radial cutting forces on the element can be resolved into the cutting forces in $x$ (normal) and $y$ (feed) directions as (Figure 1 (d)):

$$
\begin{aligned}
d F_{x j} & =-d F_{t j} \sin \Psi_{j}+d F_{r j} \cos \Psi_{j} \\
d F_{y j} & =d F_{t j} \cos \Psi_{j}+d F_{r j} \sin \Psi_{j}
\end{aligned}
$$

The resultant cutting forces on the cutter in the $x$ and $y$ directions at cutter rotation angle $\theta$ are obtained by summing the cutting force over all the cutting elements by:

$$
\begin{aligned}
& F_{x}=\int_{0}^{D_{a}}\left\{\sum_{j=1}^{N_{f}} \delta_{j}\left[K_{t} t_{j}^{m_{t}}\left(-\sin \Psi_{j}\right)+K_{r} t_{j}^{m_{r}}\left(\cos \Psi_{j}\right)\right\} d z\right. \\
& F_{y}=\int_{0}^{D_{a}}\left\{\sum_{j=1}^{N_{f}} \delta_{j}\left[K_{t} t_{j}^{m_{t}}\left(\cos \Psi_{j}\right)+K_{r} t_{j}^{m_{r}}\left(\sin \Psi_{j}\right)\right\} d z\right.
\end{aligned}
$$


$\underline{\text { It has been found that the size effect parameters }} m_{t}$ and $m_{r} \underline{\text { can be assumed to be }}$ $\underline{\text { constant for a specified material. }} K_{t}$ and $K_{r}$ change with the depth of cut and can be approximated by the polynomial (Feng and Meng, 1994) as:

$$
\begin{aligned}
& K_{t}(z)=a_{0}+a_{1}\left(\frac{z}{R_{0}}\right)+a_{2}\left(\frac{z}{R_{0}}\right)^{2}+a_{3}\left(\frac{z}{R_{0}}\right)^{3} \\
& K_{r}(z)=b_{0}+b_{1}\left(\frac{z}{R_{0}}\right)+b_{2}\left(\frac{z}{R_{0}}\right)^{2}+b_{3}\left(\frac{z}{R_{0}}\right)^{3} \\
& \hline
\end{aligned}
$$

where $a_{0}, a_{1}, a_{2}, a_{3}$ and $b_{0}, b_{1}, b_{2}, b_{3}$ are constants. Therefore, the average cutting forces on the cutter can be written as:

$$
\begin{aligned}
& A F_{x}=-f^{m_{t}}\left(a_{0} A_{0}+a_{1} A_{1}+a_{2} A_{2}+a_{3} A_{3}\right) \\
& A F_{y}=-f^{m_{r}}\left(b_{0} B_{0}+b_{1} B_{1}+b_{2} B_{2}+b_{3} B_{3}\right)
\end{aligned}
$$

where,

$$
\begin{aligned}
& A_{n}=-\frac{1}{2 \pi} \sum_{\theta=0}^{2 \pi} \sum_{z=0}^{D_{a}} \sum_{j=1}^{N_{f}}\left(\frac{z}{R_{0}}\right)^{n}\left|\sin \Psi_{j}\right|^{m_{t}+1} \Delta z \Delta \theta \\
& B_{n}=\frac{1}{2 \pi} \sum_{\theta=0}^{2 \pi} \sum_{z=0}^{D_{a}} \sum_{j=1}^{N_{f}}\left(\frac{z}{R_{0}}\right)^{n}\left|\sin \Psi_{j}\right|^{m_{r}+1} \Delta z \Delta \theta-\underline{n=0,1,2,3}
\end{aligned}
$$

The model parameters, $\mathrm{m}_{\mathrm{t}}, \mathrm{m}_{\mathrm{r},-} \mathrm{K}_{\mathrm{t}}$ and $\mathrm{K}_{\mathrm{r}}$ can be evaluated using the slot milling test data.

The cutting conditions of the model parameters calibration tests are presented in Table 1, where a brand new cutter was restricted to six cuts to minimise the effect of tool wear on the cutting force. In the first set of tests (CT1 to CT6), the depths of cut are the same while the feed rates are different. In the second and third set of tests (CT7 to

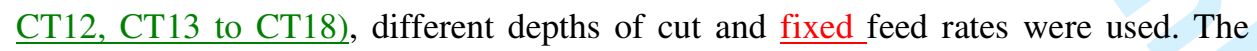
tests were carried out on a Hermle C600U 5-axis machining centre. The instantaneous cutting forces in the feed $\left(F_{y}\right)$ and the normal directions $\left(F_{x}\right)$ were measured using a 3component dynamometer, as seen in Figure 2. To avoid the effect of noise on the 
cutting force signals, samples of 20 cutter revolutions were used to calculate the average cutting forces $\left(A F_{x}, A F_{y}\right)$ in Equation 8 as presented in Table 1.

A method was developed to evaluate the size effect parameters based on the assumption that the size effect parameters are constant for a specific work-piece. Suppose the average cutting forces on the cutter for constant depth of cut can be expressed as:

$$
\begin{aligned}
& \ln \left|A F_{x}\right|=c_{0}+m_{t} \ln f \\
& \ln \left|A F_{y}\right|=d_{0}+m_{r} \ln f
\end{aligned}
$$

The plot of the log function of the cutting forces against the log function of feed rate is shown in Figure 3. It can be seen that the log function of the cutting forces has linear relationship with the log function of the feed rate. Using the linear regression method, the cutting force can be resolved as:

$$
\begin{aligned}
& \ln \left|A F_{x}\right|=6.35+0.693 \ln f \\
& \ln \left|A F_{y}\right|=3.5+0.574 \ln f
\end{aligned}
$$

Comparing Equation (10) with Equation (11), the size effect parameters were obtained as:

$$
m_{t}=0.693, m_{r}=0.574
$$

The model parameters constants $a_{0}, a_{1}, a_{2}, a_{3}$ and $b_{0}, b_{1}, b_{2}, b_{3}$ in Equation 7 were obtained using the least squares technique from Equation (8) and Equation (9). And $\underline{\text { the specific cutting pressures were given as: }}$

$$
\begin{aligned}
& K_{t}=5120-25719\left(\frac{z}{R_{0}}\right)+46678\left(\frac{z}{R_{0}}\right)^{2}-25433\left(\frac{z}{R_{0}}\right)^{3} \\
& K_{r}=231+2303\left(\frac{z}{R_{0}}\right)-4630\left(\frac{z}{R_{0}}\right)^{2}+2551\left(\frac{z}{R_{0}}\right)^{3}
\end{aligned}
$$

Formatted: Lowered by $18 \mathrm{pt}$
Deleted:

Formatted: Font: $12 \mathrm{pt}$, Font color: Black, Lowered by 32 pt 
In the ball-end milling applications, where the tests-piece is P20 (AISI), the cutting forces on the cutter can be calculated using Equations $\underline{6}, \underline{12}$ and 13 .

\section{Machining with a cutting force model}

The infinitesimal cutting force model, which has been used by Kline (1982), Kim et al (2000) and Bouzakis et al (2003) for cutting force control in cornering and sculptured surface quality machine research, was used to investigate the influence of the cutting force on the surface quality of ball-nose milled parts. A cutting force, on a randomly selected surface, can be calculated using the cutting data supplied by the cutter tool manufactures, and the cutting conditions are usually kept constant through the machining process. However, the feed rate must be adjusted, when the cutting conditions vary, according to the calculated cutting force on a specified surface. The feed rate would be reduced when the calculated cutting force is larger than the target value, or increased when the calculated cutting force is smaller. It is convenient to machine a freeform surface using a ball-end mill cutter, but it is difficult to maintain Formatted: Font color: Red the surface roughness over the whole free form surface. To reduce this complexity, the cutting process can be considered incrementally, and the cutting force on the cutter at a specific location can be determined by the cut geometry, cutter immersion condition and cutting parameters at each location point (Feng, 2001). Understanding the cutting force and its affect on simple plane surfaces is important, because plane surface machining can simplify the cutting force calculation and ease the surface roughness measurement. Therefore, a test-piece with three plane surfaces S1, S2 and S3 was machined with different depths of cut on each surface, as shown in Figure 4. 
The cutter was fed to the work-piece in the negative y direction (raster tool passes in down milling mode) with a spindle speed of $2000 \mathrm{rpm}$. The first tool path was half immersion down milling with subsequent passes having a step-over value of $0.3 \mathrm{~mm}$. Each surface was, therefore, machined with a fixed width of cut of $0.3 \mathrm{~mm}$ and a specified depth of cut of $2.0 \mathrm{~mm}, 1.2 \mathrm{~mm}$ and $0.8 \mathrm{~mm}$ for surfaces S1, S2 and S3 respectively. The cutting force for surface S1 was calculated from the cutting force model using the supplier recommended feed rate. This cutting force was considered as the target value, which would be maintained during the machining process. Likewise, when surfaces S2 and S3 were machined, the cutting forces were calculated using equation 1 and compared with the target value for surface S1. The feed rate was decreased when the cutting force was larger than the target value, and increased when the cutting force was smaller. Therefore, in this way, a constant cutting force could be maintained through the machining operation. The cutting conditions and the measured average $A F$ and maximum $M F$ cutting forces on the cutter are listed in Table $\underline{2}$. The measured surface textures and machined surface roughness values are shown in Figure $\underline{5}$.

It can be seen that the surface roughness changed very slightly across the surfaces $\mathrm{S}$, S2 and S3 from $9 \mu \mathrm{m}$ to $10 \mu \mathrm{m}$, though the depth of cut varied significantly from 2.0 $\mathrm{mm}$ to $0.8 \mathrm{~mm}$. The larger cutting force of $71 \mathrm{~N}$ on surface $\mathrm{S} 2$ produced a slightly larger surface roughness value of $10 \mu \mathrm{m}$, compared with the target value of $9 \mu \mathrm{m}$ on surface S1. The surface roughness value of surfaces S1 and S3 are the same. These results support the view that the cutting force model can be used to predict a feed rate to maintain a constant force and, therefore, ensure a constant surface quality. 


\section{Machining with feed rate optimisation software}

In this test, the shape shown in Figure $\underline{4}$ was machined using feed rates generated by commercial feed rate optimisation software, in which the removed chip volume is used as an analogue of the cutting force. In variable cutting conditions, the feed rate is adjusted based on the anticipated variation in the removed chip volume. The target feed rate is determined from the cutting data recommended by the cutting tool supplier. The cutting conditions and the recorded cutting forces are listed in $\underline{\text { Table }} \underline{3}$.

Though the depths of cut are the same as those in Table $\underline{2}$, the feed rates differ significantly. In this test, the feed per tooth was increased from $0.117 \mathrm{~mm} /$ tooth on $\mathrm{S} 1$ to $0.406 \mathrm{~mm} /$ tooth on $\mathrm{S} 3$, with corresponding depth of cut changes from $2.0 \mathrm{~mm}$ to $0.8 \mathrm{~mm}$. It is apparent from a comparison of the data in Tables $\underline{2}$ and $\underline{3}$ that the cutting forces in the latter test are larger than those in the cutting force machining trial, and that the cutting forces change considerably in variable cutting conditions. It is considered that the chip volume can not represent the actual cutting force precisely, especially in varied cutting conditions. The measured surface textures and roughness values of the machined surfaces are shown in Figure $\underline{6}$.

The surface roughness values produced by the optimisation software are significantly greater than those produced by the cutting force model, and also have a wider range of values. The roughest surface S3 $(48 \mu \mathrm{m})$ was machined with the largest cutting force $(175 \mathrm{~N})$, whereas the least rough surface S1 $(17 \mu \mathrm{m})$ had the smallest cutting force $(84 \mathrm{~N})$. 
1

2

3

4

5

6

7

8

9

10

11

12

13

14

\section{Conclusion}

In ball-end milling applications, the cutting force and the surface machining quality have a strong positive correlation. Larger cutting forces produce rougher surfaces than smaller cutting forces. The infinitesimal flute cutting force model, which controls the cutting accurately, can be used for cutting force control. Similar to all mechanistic cutting force models, it requires considerable effort to calibrate and ascertain the parameters for specific combinations of material and cutting media. The machining trials demonstrated that the cutting force model was able to maintain a relatively constant surface quality between $9 \mu \mathrm{m}$ and $10 \mu \mathrm{m}$, whilst maintaining the average cutting force in the range $62.8 \mathrm{~N}$ to $71.7 \mathrm{~N}$. Using the chip volume removal rate as an analogue of cutting force does not control the cutting force precisely. The average cutting force varied by $104 \%$, and the machined surface roughness values ranged from $17 \mu \mathrm{m}$ to $48 \mu \mathrm{m}$. The results of the investigation supports the view that consistent surface finishes can be produced by maintaining the cutting forces at desired levels with feed rate control strategies.

\section{Acknowledgements}

The authors wish to thank Delcam International and the School of Engineering at the University of Birmingham for their financial support of the project.

\section{References}

1. BERGS, T. and ALTINTAS, Y., 1996, Tool path optimisation for finish milling of die and mold surfaces- software development, Transactions of

Formatted: Numbered + Level: $1+$ Numbering Style: $1,2,3, \ldots+$ Start at: 1 + Alignment: Left + Aligned at: $18 \mathrm{pt}+$ Tab after: $36 \mathrm{pt}+$ Indent at: $36 \mathrm{pt}$ 
2. BAYOUMI, A.E., YUCESAN, G. and KENDALL, L. A., 1994, An analytic mechanistic cutting force model for milling operations: a theory and methodology, ASME Journal of Emgineering for Industry, 116, 324-330.

3. BOUZAKIS, K. D, AICHOUH, P., 2003, Efstathiou, K., Determination of the Chip Geometry, Cutting Force and Roughness in Free Form Surfaces Finishing Milling, with Ball-End Tools, International Journal of Machine Tools \& Manufacture, Vol. 43, p. 499-514.

4. CHU, C. N., KIM, S. Y., LEE, J. M. KIM, B. H., 1997, Feed-Rate Optimisation of Ball-End Milling Considering Local Shape Features, Annals of the CIRP, Vol. 46 (1), p. $433-436$.

5. Devor, R. E., 1998, Mechanistic Model for the Force System in End Milling with Application to Machining Airframe Structures, Manufacturing Engineering Transactions, p. 297-300.

6. GADALLA, M. AND ELMARAGHY, W. H., 1998, Parametric Surface Offsetting Using Surface Subdivision with Application to Free Form Surface Machining and Accuracy Improvement, The International Journal for Manufacturing Science \& Production, Vol. 1 (2),

7. FENG, H. Y. AND SU, N., 2001, A Mechanistic Cutting Force Model for 3-D Formatted: Justified Formatted: Bullets and Numbering Ball-End Milling, Journal of Manufacturing Science and Engineering, Vol. 123 , p. $23-29$

8. FENG, H. Y and MENG, C. H, 1994, The prediction of cutting forces in the ball-end milling process-I. Model formulation and model building procedure, International Journals of Machine Tool Manufacturing, 34(5), p. 697-710. 
9. KIM, G. M., CHO, P. J. AND CHU, C. N., 2000, Cutting Force Prediction of Sculptured Surface Ball-End Milling Using Z-Map, International Journals of Machine Tool Manufacture, Vol. 40, p.277-291.

10. KLINE W. A, DEVOR, R. E. and LINDBERG, J. R, 1982, The prediction of cutting forces in end milling with application to cornering cuts, International Journals of Machine Tool Design and Research, 22(1), 7-22.

11. LUTTERVELT VAN, C. A, CHILD, T. H. C, JAWAHIR, I. S, KLOCKE, F., VENUVINOD, P. K.,1998, Present and Future Trends in Modelling of Machining Operations, Progress Report of the CIRP Working Group 'Modelling of Machining Operations', Annals of the CIRP, Vol. 47(2), p. 587625.

12. LEE, P. AND ALTINTAS, Y., 1996, Prediction of Ball-end Milling Forces from Orthogonal Cutting Data, International Journals of Machine Tool and Manufacturing, Vol.36 (9), p. 1059-1072.

13. LIN, S. C. AND YANG, R. J., 1995, Force-Based Model for Tool Wear Monitoring in Face Milling, International Journal of Machine Tools \& Manufacture, Vol. 35, p. 1201-1211.

14. MARTElloti, M. E., 1945, An Analysis of the Milling Process Part IIDown Milling, Trans. ASME, Vol. 67, p. 233-251.

15. Martelloti, M. E., 1944, An Analysis of The Milling Process, Trans. ASME, Vol. 63, p. 677-700.

16. MERCHANT, M. E., 1945, Mechanics of the Metal Cutting Process, Journal of applied physics, Vol. 16, No. 5, P267, and No.6, P318,

17. SABBERWAL, A. J. P., 1960, Chip Section and Cutting Force During the Milling Operation, C.I.R.P. Annul, p. 197- 203. 
18. SARHAN, A. SAYED, R. NASSR, A. A. EL-ZAHRY, R. M., 2001, Interrelationships Between Cutting Force Variation and Tool Wear in EndMilling, Journal Of Materials Processing Technology, Vol. 109, p. 229-235.

19. YANG, M. AND PARK, H., 1991, The Prediction Cutting Force in Ball-End Milling, International Journals of Machine Tool and Manufacturing, Vol. 31 (1), p. 45-54. 


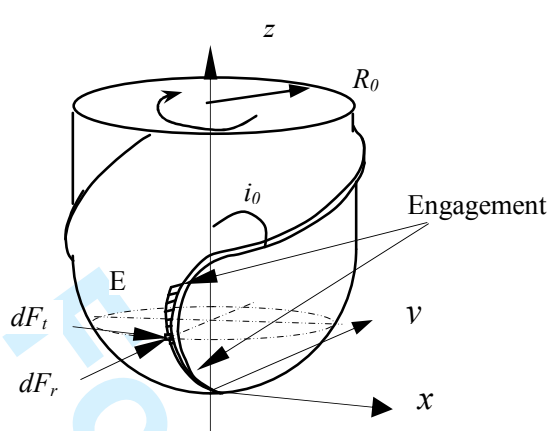

(a) Ball-end mill cutter

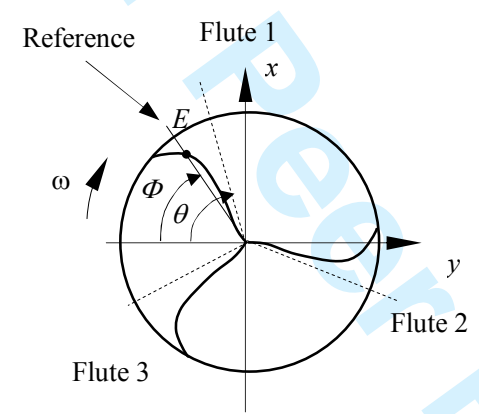

(c) Angular position of flute

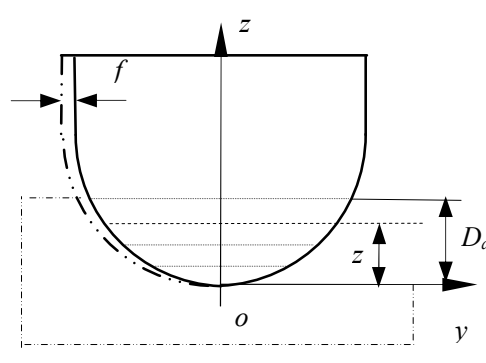

(b) Infinitesimal discs of cutter

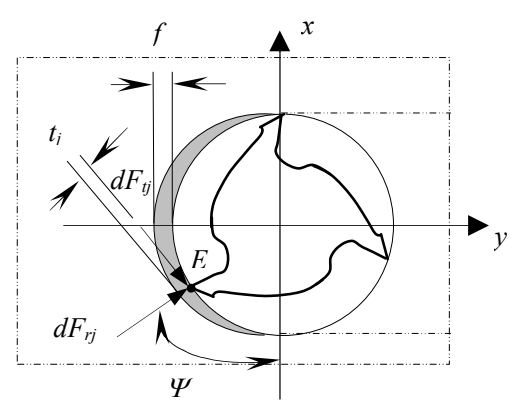

(d) Cutting forces on a disc

Figure 1 Infinitesimal cutting force model for a ball-end milling cutter 


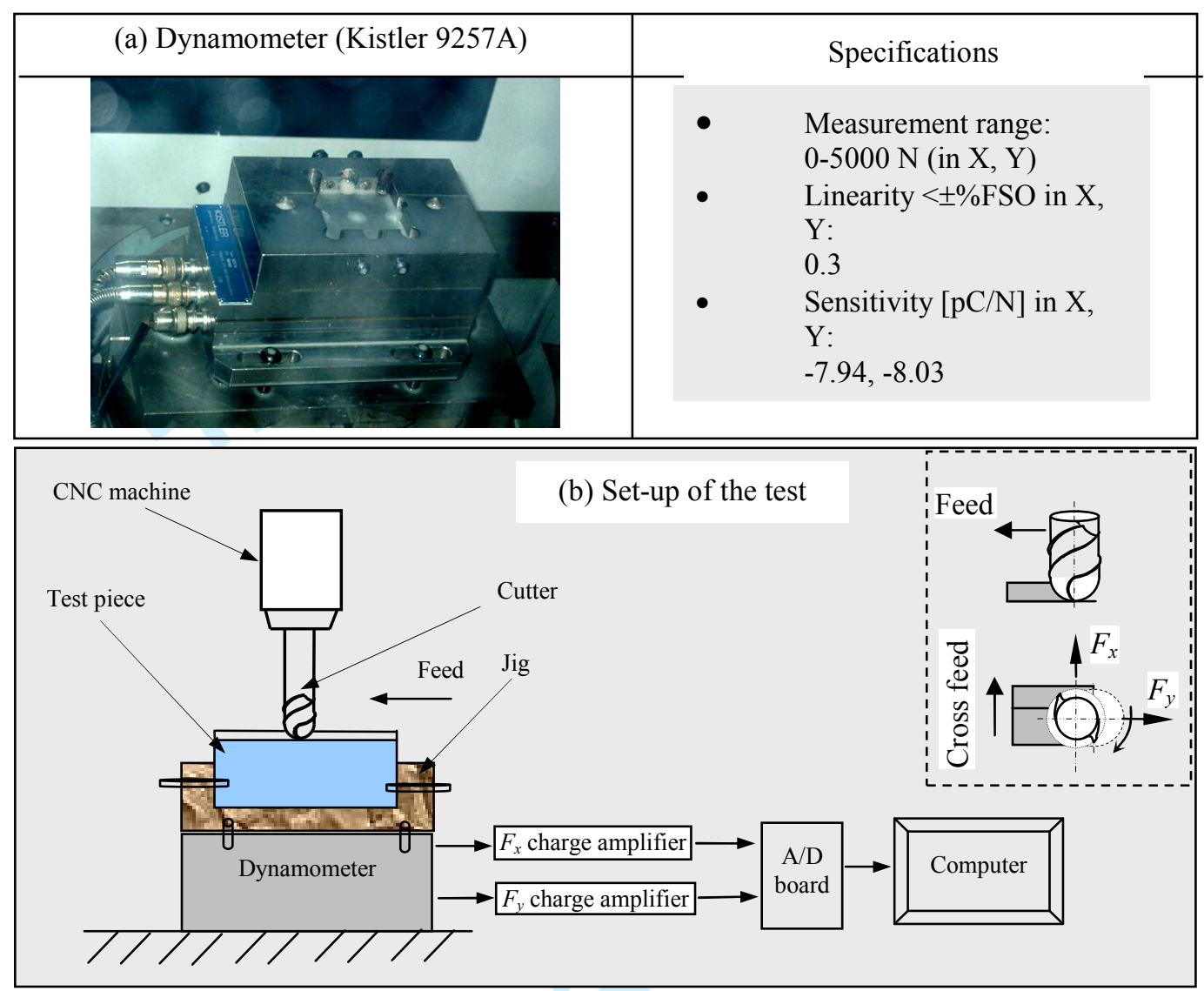

Figure 2 Dynamometer and test set-up arrangement

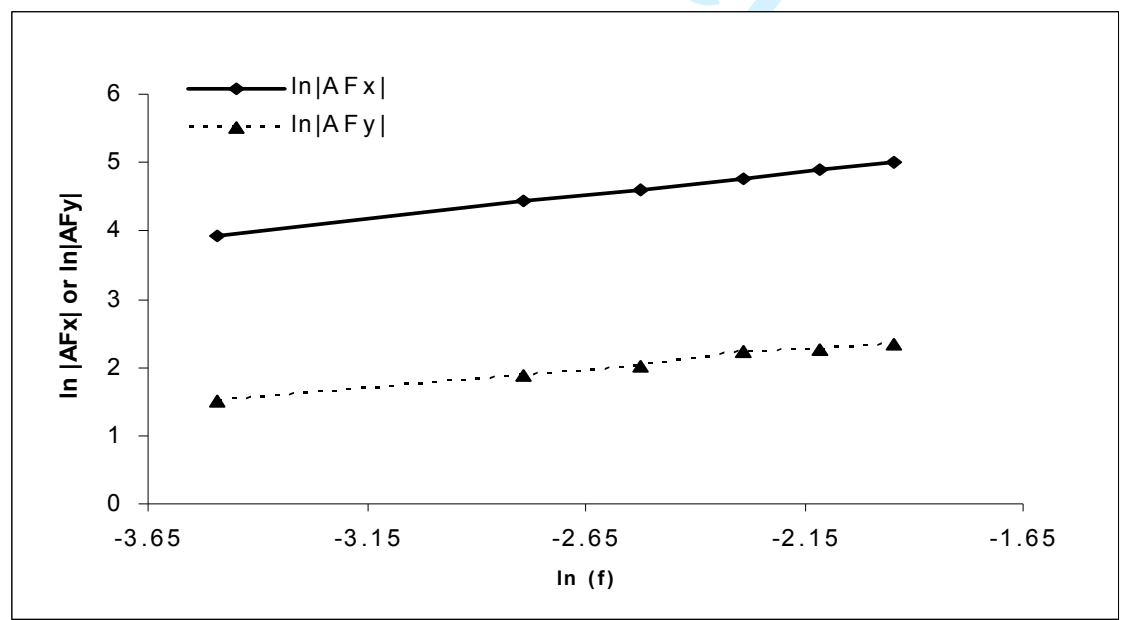

Figure 3 Relationships between cutting forces and feed rate 


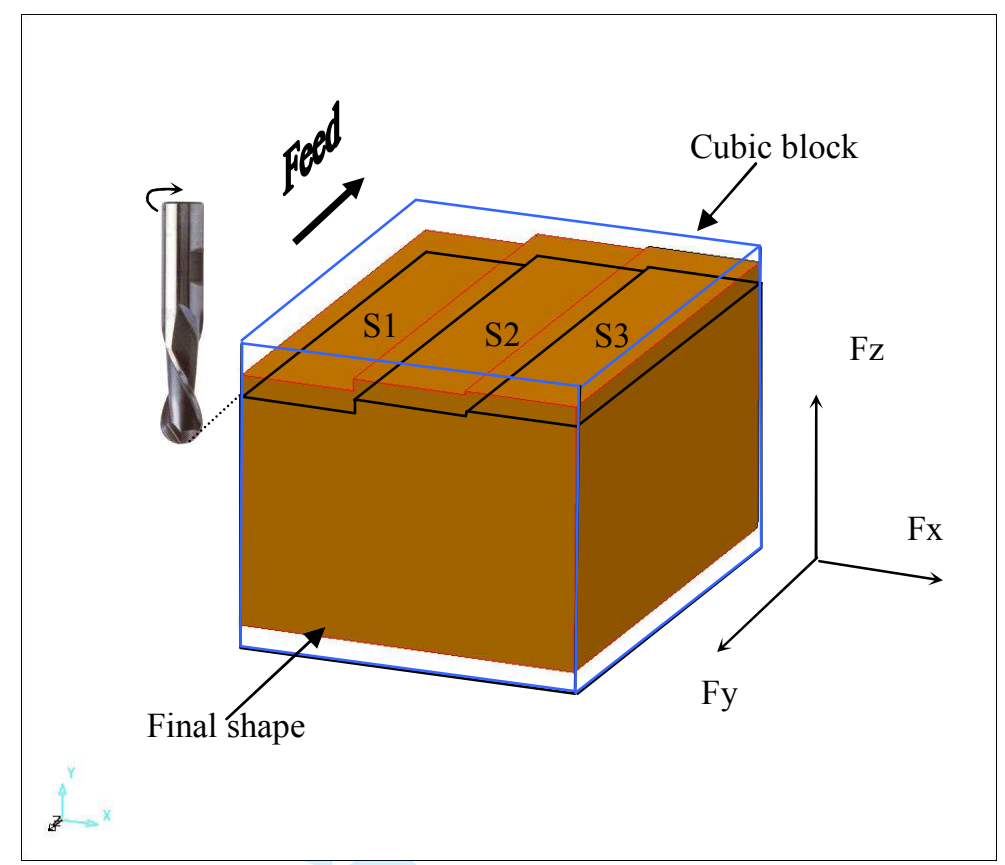

Figure 4 Three plane test-piece

http://mc.manuscriptcentral.com/tprs Email: ijpr@lboro.ac.uk 


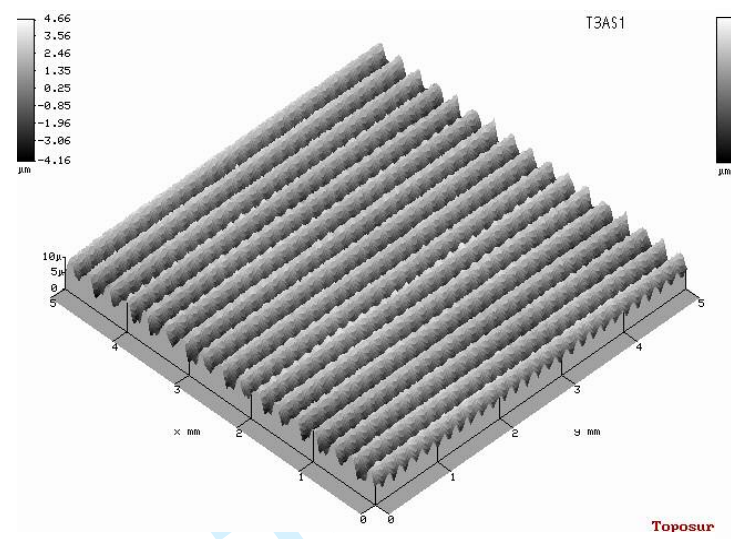

(a) $\mathrm{S} 1: \mathrm{R}_{\mathrm{a}}=9 \mu \mathrm{m}$

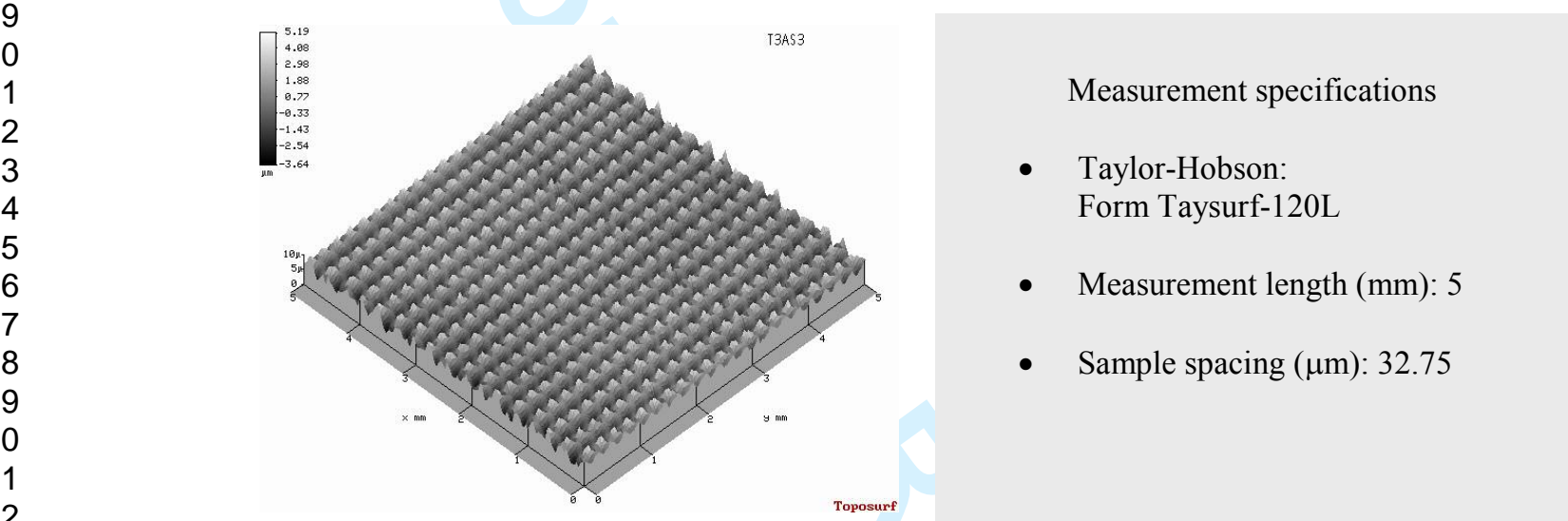

(c) $\mathrm{S} 3: \mathrm{R}_{\mathrm{a}}=9 \mu \mathrm{m}$

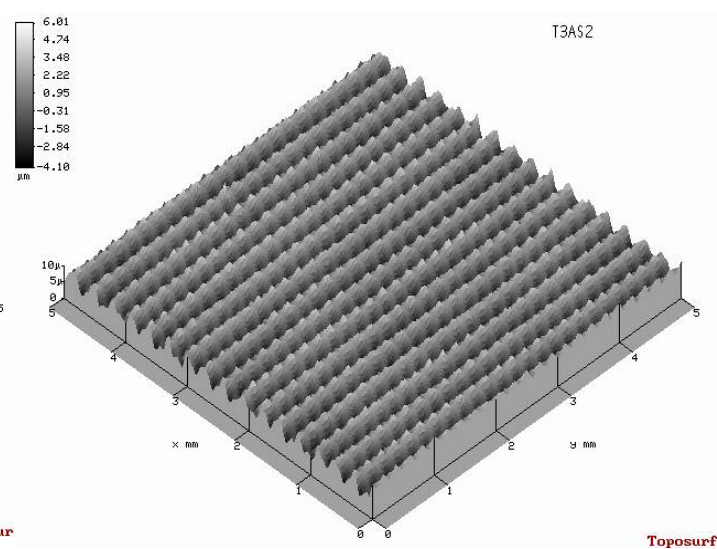

(b) $\mathrm{S} 2: \mathrm{R}_{\mathrm{a}}=10 \mu \mathrm{m}$

Figure 5 Surface roughness values from the cutting force model tests 


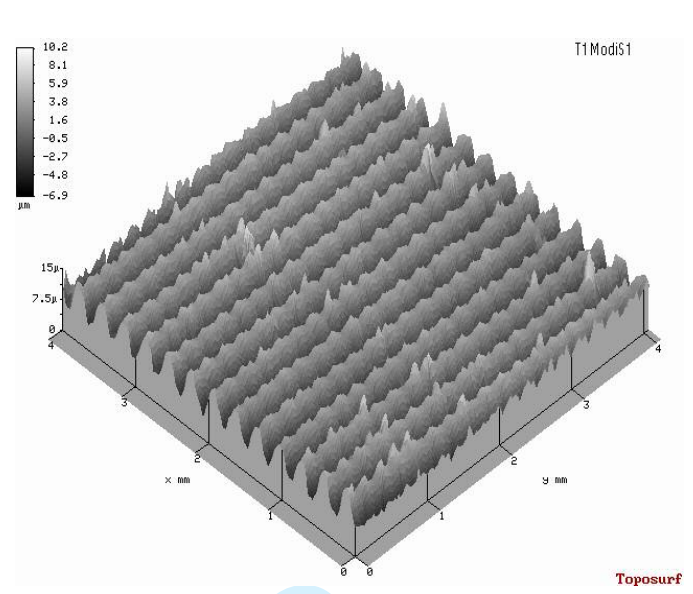

(a) $\mathrm{S} 1: \mathrm{R}_{\mathrm{a}}=17 \mu \mathrm{m}$

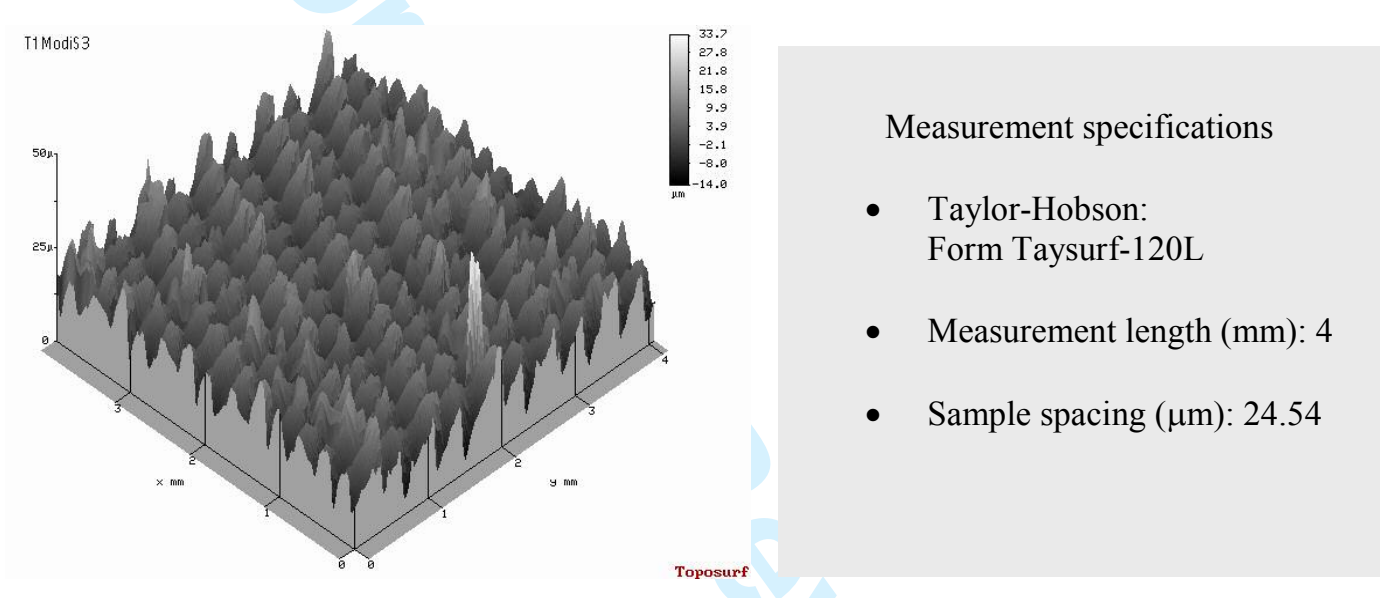

(c) $\mathrm{S} 3: \mathrm{R}_{\mathrm{a}}=48 \mu \mathrm{m}$

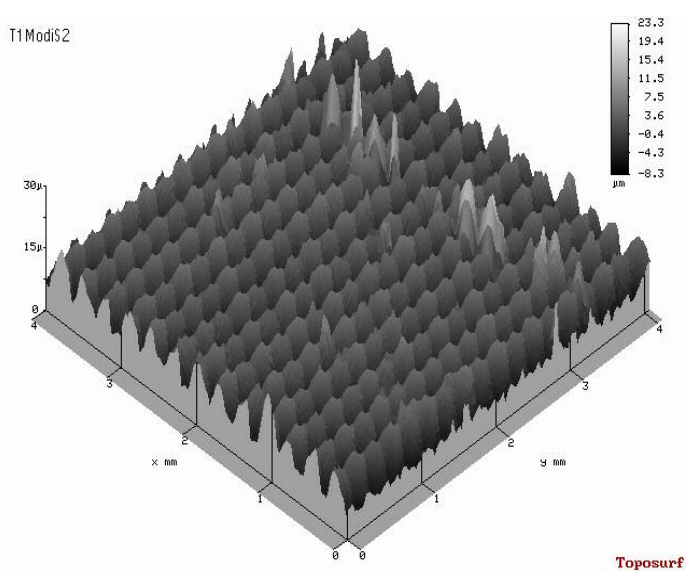

(b) $\mathrm{S} 2: \mathrm{R}_{\mathrm{a}}=32 \mu \mathrm{m}$

Figure 6 Surface roughness values from the feed rate optimisation software 


\begin{tabular}{|c|c|c|c|c|c|}
\hline \multirow{2}{*}{ No } & \multirow{2}{*}{$\begin{array}{c}\text { Depth } \\
\mathrm{mm}\end{array}$} & \multirow{2}{*}{$\begin{array}{c}\text { Feed } \\
\text { rate } \\
\mathrm{mm} / \mathrm{t} \text { tot }\end{array}$} & $\begin{array}{c}\text { Spindle } \\
\text { speed } \\
\mathrm{rpm}\end{array}$ & \multicolumn{2}{|c|}{$\begin{array}{c}\text { Measured cutting } \\
\text { force }\end{array}$} \\
\cline { 5 - 6 } & & & $A F_{x}$ & $A F_{y}$ \\
\hline CT1 & 0.24 & 0.0304 & 2000 & -51.2 & 4.5 \\
\hline CT2 & 0.24 & 0.0614 & 2000 & -83.6 & 6.5 \\
\hline CT3 & 0.24 & 0.0802 & 2000 & -99.8 & 7.6 \\
\hline CT4 & 0.24 & 0.1016 & 2000 & -115.9 & 9.4 \\
\hline CT5 & 0.24 & 0.1205 & 2000 & -134.9 & 9.6 \\
\hline CT6 & 0.24 & 0.1431 & 2000 & -149.8 & 10.5 \\
\hline CT7 & 0.24 & 0.0304 & 2000 & -49.2 & 4.5 \\
\hline CT8 & 0.92 & 0.0304 & 2000 & -138.3 & 31.2 \\
\hline CT9 & 1.43 & 0.0304 & 2000 & -166.2 & 56 \\
\hline CT10 & 1.98 & 0.0304 & 2000 & -160.7 & 62.9 \\
\hline CT11 & 2.13 & 0.0304 & 2000 & -175.5 & 73.3 \\
\hline CT12 & 2.82 & 0.0304 & 2000 & -211 & 95 \\
\hline CT13 & 0.24 & 0.0614 & 2000 & -81.3 & 6.5 \\
\hline CT14 & 0.77 & 0.0614 & 2000 & -172.6 & 36 \\
\hline CT15 & 1.22 & 0.0614 & 2000 & -221.1 & 60.9 \\
\hline CT16 & 1.98 & 0.0614 & 2000 & -276.4 & 114.6 \\
\hline CT17 & 2.53 & 0.0614 & 2000 & -333.4 & 162 \\
\hline CT18 & 2.82 & 0.0614 & 2000 & -341.1 & 161.4 \\
\hline
\end{tabular}

Table 1 Cutting conditions and measured cutting forces for the model parameter calibration tests

\begin{tabular}{|c|c|c|c|c|}
\hline Surface & $\begin{array}{c}\text { Depth of cut } \\
(\mathrm{mm})\end{array}$ & $\begin{array}{c}\text { Feed rate } \\
(\mathrm{mm} / \text { tooth })\end{array}$ & \multicolumn{2}{|c|}{ Measured cutting force } \\
(From model) & $A F$ & $M F$ \\
\hline S1 & 2 & 0.088 & 62.8 & 406 \\
\hline S2 & 1.2 & 0.104 & 71.7 & 425 \\
\hline S3 & 0.8 & 0.117 & 68.9 & 403 \\
\hline
\end{tabular}

Table 2 Measured cutting forces from the cutting force model tests

\begin{tabular}{|c|c|c|c|c|}
\hline Surface & $\begin{array}{c}\text { Depth of cut } \\
(\mathrm{mm})\end{array}$ & \multicolumn{2}{|c|}{$\begin{array}{c}\text { Feed rate } \\
\text { (mm/tooth) } \\
\text { (From Sftware) }\end{array}$} & \multicolumn{2}{|c|}{ Measured cutting force } \\
\hline S1 & 2.0 & 0.117 & 84 & 359 \\
\hline S2 & 1.2 & 0.235 & 128 & 460 \\
\hline S3 & 0.8 & 0.406 & 175 & 554 \\
\hline
\end{tabular}

Table 3 Measured cutting forces from the feed rate optimisation software 